\title{
The prospects and challenges of cassava inclusion in wheat bread policy in Nigeria
}

\section{Elijah Ige Ohimain}

Industrial and Food Policy Research Unit, Department of Biological Sciences, Faculty of Science, Niger Delta University, Bayelsa State, Nigeria

\section{Email address:}

eohimain@yahoo.com

\section{To cite this article:}

Elijah Ige Ohimain. The Prospects and Challenges of Cassava Inclusion in Wheat Bread Policy in Nigeria. International Journal of Science, Technology and Society. Vol. 2, No. 1, 2014, pp. 6-17. doi: 10.11648/j.ijsts.20140201.12

\begin{abstract}
Nigeria is a large country of nearly one million square kilometers. The population of the country is rapidly increasing, reaching 167 million in 2012. Due to urbanization and changes in lifestyle, bread is increasingly being consumed in the country. Wheat performs poorly under Nigerian climate; hence the country spends huge foreign exchange for the importation of wheat. Nigeria spent $\$ 635$ billion Naira (US $\$ 1=156$ ) on the importation of wheat in 2010 alone. The country is therefore spending nearly 1.8 billion daily for wheat importation. The Federal Government of Nigeria (FGN) planned to reduce wheat importation by implementing 40\% cassava inclusion in bread policy in July 2012 . This paper appraised the benefits and challenges of the $40 \%$ cassava inclusion in bread policy. The benefits of the policy include increased domestic agricultural productivity, food security, foreign exchange savings, employment generation, and wealth creation. On the other hand, implementation of the policy could precipitate several challenges including lack of enough domestic capacity to generate the volume of cassava flour needed to actualize the policy, increased smuggling of wheat, poor cassava flour supply chains, weak policy implementation, technology and processing challenges, reluctance of millers to use cassava flour, and cassava bread policy instability. Unless, these challenges are addressed the current attempt of $40 \%$ cassava inclusion policy could fail like previous attempts.
\end{abstract}

Keywords: Composite Flour, Food Policy, HQCF, Wheat Substitution

\section{Introduction}

Bread is conventionally produced from wheat (Triticum aestivum Desf.) flour. Bread is also made, though to a lesser extent, from the flour of other wheat species including T. durum, T. dicocum and T. spelta (Komlaga et al., 2012). Bread has now become one of the most widely consumed foods in the world. Bread is an important staple food both in the developed and developing world (Abdelghafor et al., 2011). In India, bread has become one of the most widely consumed non-indigenous food (Das et al., 2012), whereas in Nigeria, bread has become the second most widely consumed non-indigenous food after rice (Shittu et al., 2007). The rapid urbanization, increasing population and changing food habits have resulted in the preference for convenient foods such as bread, biscuits, and other baked products (Oyewole et al., 1996; Ogunjobi and Ogunwole, 2010; Adebowale et al., 2012).

Bread has been described as an unstable elastic solid foam containing a continuous phase of elastic network of cross linking gluten molecules and starch polymer, mostly amylase, and a discontinuous phase of entrapped, partially gelatinized, swollen and deformed starch granules (Osella et al., 2005; Gray and BeMiller, 2003). Bread is normally made from wheat flour dough that is cultured with yeast, allowed to rise, and baked (Komlaga et al., 2012). The unique bread-making properties of wheat flour areattributed mainly to the ability of its gluten to form a viscoelastic network when mixed with water (Defloor et al., 1993). Aboaba and Obakpolor (2010) reported that gluten gives wheat dough an elastic structure that allows the retention of gas bubbles in an intact structure, resulting in a sponge-like textured final product, a feature that is highly desirable in bread. Dough leavened with yeast catalyzes the fermentation of sugar resulting in the production of bubbles of carbon dioxide which is trapped by the gluten network causing the dough to rise or swell (Alvarenga et al., 2011). Gluten is a composite of prolamin and glutein, which exists, 
conjoined with starch, in the endosperm of various grass related grains particularly wheat (Alvarenga et al., 2011) and other grains such as barley, rye and triticale (Komlaga et al., 2012) whereas oats and maize, though being grasses, do not contain gluten (Houben et al., 2012).

The continuous use of wheat in bread making is faced with two challenges (1) the development of celiac (coeliac) disease and (2) wheat performs poorly under tropical climates. Celiac disease, which is caused by a reaction to gluten, is an auto-immune disorder of the small intestine causing an inflammatory reaction, which interferes with the absorption of nutrients particularly proteins and minerals (Alvarenga et al., 2011). In recent years, perhaps owing to better diagnostics, there has been increasing incidence of celiac diseases (Houben et al., 2012). Pite (2008) reported that $0.5 \%$ of Europeans suffer from celiac diseases. A 1996 statistics show that the following ratio of people are suffering from celiac disease in different countries including Ireland (1:300), Norway (1:1200), Canada (1:2000), US (1:5000) (FAO and IFAD, 2004).

Despite the increasing consumption of bread in tropical countries, wheat performs poorly under tropical climates. Hence, huge amounts of money (foreign exchange) are spent on wheat importation annually in these countries. Nigeria spent 635 billion Naira (US $\$ 1=156$ ) on the importation of wheat in 2010 alone. The country is therefore spending nearly 1.8 billion daily for wheat importation (Momoh, 2011). Nigeria wheat imports increased from 56,000 tonne in 1965 through 0.41 million tonne in 1975 to 1.67 million tonne/annum in 1984 (Dendy, 1992), whereas Ghana wheat imports was 300,000 tonne in the 1990s (FAO and IFAD, 2004). Nigeria wheat importation is growing at the rate of $13 \%$ per year and could reach 17 million metric tonnes by 2020 (Olanrewaju, 2012). Nigeria imports about 15 million metric tonnes of wheat flour yearly for the production of bread (Ogunbawo et al., 2008). The rippling effect of this high wheat importation in Nigeria includes loss of employment to foreign nations, food insecurity, increase in food miles, trade imbalance, overdependence on foreign foods, loss of foreign exchange, high domestic prices of bread, etc. Nigeria is planning to reduce these negative trends by partially substituting wheat with cassava for the production of composite bread. Composite flouris the name given to wheat that has been diluted with other flours (Sanni et al., 2004).

Cassava, Manihot esulenta Cranz., is the chief source of dietary food energy for the majority of the people living in the low land tropics and much of the sub-humid tropics of west and central Africa (Echebiri and Edaba, 2008). It has been estimated that $600-700$ million people obtain more than $500 \mathrm{cal} /$ day from cassava (Maziya-Dixon et al., 2007; Nuwamanya et al., 2010). Africa accounts for about half of the total world cassava production. In 2005/2006 Nigeria produced 35 - 40 million metric tonnes of cassava (Ituen and Ituen, 2011). Nigeria the largest producer of cassava in the world, harvested 36.8 million tonnes from 3.13 million ha with an average yield of 11.7 tonnes/ha (Babatunde, 2012).
Local varieties of cassava produce an average of 12 tonnes/ha while improved varieties produce up to 25 tonnes/ha (Tarawali et al., 2012). There are over 400 varieties of cassava cultivated in Nigeria providing income for over 30 million people (Adebile, 2012). Nearly 90\% of the cassava produced in Nigeria is used for food, while the rest is used industrially for the production of animal feed, ethanol, glucose syrup, starch (UNIDO/FGN, 2006). For instance, of the 32 million tonnes of cassava produced in 2001 , $84 \%$ was consumed as food, while only $16 \%$ was utilized as industrial raw material (Phillips et al; 2004).Nigeria wants to partially substitute wheat with cassava to $40 \%$ for the production of composite flour for bread, pasta and other confectionaries. The $40 \%$ cassava inclusion in flour policy is expected to reduce wheat importation, spur rural development, create jobs, and help to reduce the trade imbalance between Nigeria and wheat producing countries. This is not the first time that Nigeria has attempted to partially substitute wheat. Other previous efforts had failed. Hence, the aim of this study is to appraise the $40 \%$ cassava inclusion in bread policy (2012) with a view of highlighting both the potential prospects and challenges and attempt to learn from the failures of previous cassava inclusion in wheat flour policies, in order to avert such pitfalls in the implementation of the current policy.

\section{Cassava Inclusion Policy (Current and Previous Attempts)}

The Federal Government of Nigeria (FGN) released the $40 \%$ cassava inclusion in wheat flour policy which became effective 15 July, 2012. The policy mandated flour mills and bakers to incorporate $40 \%$ cassava flour into wheat flour for the production of composite flour that will be used for bread making, pasta and other confectionaries. The policy is aimed at accelerating the pace of cassava utilization in the country and to make Nigeria both the largest producer and processor of cassava products. By implementing the policy, Nigeria planned to expand the current cassava production from 35 to 51 million tonnes per year. Incentives included in the policy include:

Import duty waivers for the importation of cassava processing and composite flour blending equipment.

Corporate tax rebate of $12 \%$ for bakery using cassava wheat composite flour for bread making.

Effective from $15 / 02 / 2012$, the $10 \%$ tariff on bread improvers shall be removed.

Introduction of high yielding and disease resistant varieties of cassava.

Smallholder bakers shall be given free starter packs containing composite flours and bread improvers for 100 $\mathrm{kg}$ of bread.

Small scale farmers shall be provided with two bags of $50 \mathrm{~kg}$ fertilizer at half the price plus 15 bundles of improved cassava varieties for free.

A levy of $65 \%$ shall be added to the existing $35 \%$ duty 
on wheat flour importation, while a levy of $15 \%$ shall be added to the existing $5 \%$ duty on wheat grain.

Establishment of cassava bread development fund (CBDF), which would be funded by the new levies on wheat flour and grains.

The CBDF shall be used to train all the over 400,000 master bakers in Nigeria.

Prohibition of importation of cassava flour.

Loans shall be provided for the purchase of cassava processing equipment.

Flour millers and bakers have been given18 month transition period for composite flour.

Toward the success of the policy, several players have been assigned different, but complimentary roles (Table 1).

Table 1. Policy players and their roles.

\begin{tabular}{|c|c|}
\hline Agency/player & Roles \\
\hline Ministry of Trade and Investment & $\begin{array}{l}\text { Coordination of investment in } \\
\text { the cassava bread subsector }\end{array}$ \\
\hline $\begin{array}{l}\text { Ministry of Agriculture and Rural } \\
\text { development }\end{array}$ & Farmers support \\
\hline $\begin{array}{l}\text { State Agricultural Development } \\
\text { Programme }\end{array}$ & Farmers support \\
\hline $\begin{array}{l}\text { Small and Medium Enterprises } \\
\text { Development Agency (SMEDAN) }\end{array}$ & Farmers support \\
\hline $\begin{array}{l}\text { International Institute for Tropical } \\
\text { Agriculture (IITA) }\end{array}$ & $\begin{array}{l}\text { Research, development \& } \\
\text { demonstration }\end{array}$ \\
\hline $\begin{array}{l}\text { National Root Crop Research } \\
\text { Institute (NRCRI) }\end{array}$ & $\begin{array}{l}\text { Research, development \& } \\
\text { demonstration }\end{array}$ \\
\hline Bank of Industry & Financial support \\
\hline $\begin{array}{l}\text { Nigerian Agriculture and Rural } \\
\text { Development Bank }\end{array}$ & Financial support \\
\hline $\begin{array}{l}\text { Standard Organization of Nigeria } \\
(\mathrm{SON})\end{array}$ & Quality control \\
\hline National Agency for Food, Drug & \\
\hline $\begin{array}{l}\text { Administration and Control } \\
\text { (NAFDAC) }\end{array}$ & Quality control \\
\hline $\begin{array}{l}\text { Federal Institute of Industrial } \\
\text { Research (FIIRO) }\end{array}$ & $\begin{array}{l}\text { Research, development \& } \\
\text { demonstration }\end{array}$ \\
\hline $\begin{array}{l}\text { Raw materials Research and } \\
\text { Development Council (RMRDC) }\end{array}$ & $\begin{array}{l}\text { Research, development \& } \\
\text { demonstration }\end{array}$ \\
\hline Nigeria Export Promotion Council & $\begin{array}{l}\text { Coordinate export of cassava } \\
\text { products }\end{array}$ \\
\hline Nigerian Custom Service & $\begin{array}{l}\text { Border control to prevent } \\
\text { importation of cassava products }\end{array}$ \\
\hline Flour Mills & $\begin{array}{l}\text { Production of composite flour } \\
\text { using HQCF }\end{array}$ \\
\hline $\begin{array}{l}\text { Nigerian Cassava Growers } \\
\text { Association }\end{array}$ & Cassava farming and processing \\
\hline $\begin{array}{l}\text { Manufacturers Association of } \\
\text { Nigeria }\end{array}$ & Incorporation of HQCF \\
\hline Master Bakers & Production of cassava bread \\
\hline
\end{tabular}

\subsection{Implementation of Policy}

$10 \%$ cassava inclusion in wheat created a demand of 300,000 tonnes of high quality cassava flour (HQCF) per year (Sawyerr, 2012; UNIDO/FGN, 2006).David (2011)reported 350,000 tonnes, while Falade and Akingbola (2008) reported 200,000 metric tonnes, whereas some other authors reported 250,000 metric tonnes/year, and Sanni et al.(2009) reported 330,000 tonnes. Hence 40\% inclusion could require 1.2 million tonnes of $\mathrm{HQCF} /$ year, an equivalent of 4.8 million tonnes of cassava tuber per year. Sawyerr (2012) reported that based on $10 \%$ cassava inclusion, Nigeria flour mills require $700-800$ metric tonnes of HQCF daily. Potential benefits of the $40 \%$ cassava inclusion policy include:

$10 \%$ wheat substitution could save Nigeria $\$ 63.5$ billion, while $40 \%$ could save the country $\$ 254$ billion annually.

Implementation of the policy could stimulate demand of cassava, eradicate glut, encourage utilization of locally produced commodities and create multiplier effects on employment.

Implementation of the policy will result in the dilution of gluten, which could reduce the severity of coeliac disease.

Implementation of $40 \%$ cassava bread policy could create 1.4 million jobs in 4 years (Ikuomola, 2012). Oludiran (2012) reported that implementation of the policy could create 1600 jobs in the HQCF plants and over 250,000 jobs in the sector.

The Cassava Adding Value for Africa (CAVA) Project has been reported to improve the livelihoods and incomes of about 90,000 smallholders in Ghana, Tanzania, Uganda, Malawi, and Nigeria (Westby et al., 2011)

\subsection{Achievement Thus Far}

Some of the modest achievements thus far since the $40 \%$ cassava inclusion in bread policy came into effect in July 2012;

FGN has commenced the importation and installation of 18 large scale HQCF plants from China that would mill 1.3 million metric tonnes of HQCF per year and are due for operation in 18 - 24 months (Oyebode and Akinola, 2012).

FGN has also planed the importation of 700 compost mills for blending composite cassava wheat flour (Nigerian Tide, 2012).

Some large scale bakers such as UTC, Food Concepts, and Butter Field Bakeries have already commercialized 20\% composite cassava bread and confectionaries (Vanguard, 2012).

\subsection{Causes of Failures of Previous Cassava Bread Policies in Nigeria}

Despite the modest achievement thus far, there is the need to assess the cause of the previous efforts at partially substituting wheat in Nigeria in order to avoid the pitfalls in this current policy. Table 2 presents the list of previous cassava inclusion policies in Nigeria. 10\% cassava inclusion policy was first introduced by the president Shehu Shagari administration in 1982 and was discontinued after regime change in 1983 (Adeloye, 2012). In an attempt to encourage the domestic production of wheat, Nigeria banned the importation of wheat in January 1987 (Sanni et al., 2004; Dendy, 1993) thus saving about \$500 million per year (Dendy, 1992). The ban on the importation of wheat lasted for nearly four years and was lifted in 1990, when wheat importation resumed (Bokanga, 1995; FAO and IFAD, 2004). The ban on wheat importation forced flours 
millers to seek alternatives to wheat. Although wheat is being grown under irrigation in Northern Nigeria, the production is too low compared to the nation's annual demand (Dendy, 1993). Domestic wheat production in Nigeria increased from 1,500 tonnes in 1965 to 45,000tonnes in 1985, which represented only $2.7 \%$ wheat consumption in the country (Dendy, 1992). In 1991, the domestic production of wheat in Nigeria was 23,000 tonnes (Bokango, 1995).

Table 2. Changes in wheat importation policy in Nigeria.

\begin{tabular}{|c|c|c|}
\hline Regime & Wheat policy/year & References \\
\hline Shehu Shagari (1979 - 1983) & $10 \%$ cassava bread & Adeloye (2012) \\
\hline Ibrahim Babangida & Ban on wheat importation (1987)for 4 years & $\begin{array}{l}\text { Mkpong et al., 1990; Falade and Akingbala, 2008; Sanni et } \\
\text { al., } 2004\end{array}$ \\
\hline Olusegun Obasanjo (1999-2007) & $10 \%$ cassava inclusion in composite wheat flour & $\begin{array}{l}\text { Owuamanam, 2007; Defloor et al., 1991; Shittu et al., } \\
\text { 2007; Adeniji et al., } 2010\end{array}$ \\
\hline UmaruYar $\square$ Adua (2007 -2010) & $5 \%$ cassava inclusion in composite wheat flour & Adeloye (2012) \\
\hline Goodluck Jonathan (2010 - date) & $40 \%$ cassava inclusion in bread making & Sawyerr (2012) \\
\hline
\end{tabular}

Table 3. Reasons for the failure of previous cassava-inclusion in bread policy in Nigeria.

\begin{tabular}{|c|c|}
\hline Reasons & References \\
\hline Policy inconsistencies i.e. lack of continuity by respective government & See Table 2 \\
\hline Lack of enabling policy environment & Oludiran2012 \\
\hline Unreliable supply of HQCF & $\begin{array}{l}\text { Oludiran2002; UNIDO/FGN, 2006; Sawyerr, 2012; Ajao and Adegun, } \\
2009\end{array}$ \\
\hline Lack of willingness by the flour millers to comply with government policy & Oludiran (2002); Sanni et al., 2005 \\
\hline Lack of knowledge on the advantages of cassava wheat composite bread & Oludiran (2012) \\
\hline Presence of impurities such as sand & UNIDO/FGN, 2006 \\
\hline Foul odour, and colour problems & UNIDO/FGN, 2006 \\
\hline Shorter product shelf life & UNIDO/FGN, 2006 \\
\hline Supply of partially fermented cassava flour resulting in poor product quality & UNIDO/FGN, 2006; Sanni et al., 2005 \\
\hline Low wheat prices relative to HQCF & FAO and IFAD, 2004 \\
\hline High cost of HQCF production (fuel, transportation cost, labour) & Falade and Akinbala, 2008; Abass et al., 1998 \\
\hline Low demand of HQCF and lack of market access & Falade and Akinbala, 2008; Abass et al., 1998 \\
\hline Lack of working capital & Falade and Akinbala, 2008; Abass et al., 1998 \\
\hline Dependence on weather for drying & Falade and Akinbala, 2008; Abass et al., 1998 \\
\hline Weak supply lines of HQCF & Sanni et al., 2005 \\
\hline Strong consumer preference for $100 \%$ wheat bread & Sanni et al., 2005 \\
\hline Frequent breakdown of processing equipment & Rohi Biotechnologies Ltd (personal communication) \\
\hline Fuel inefficient flash dryers & Rohi Biotechnologies Ltd (personal communication) \\
\hline Flour mills not designed to mill HQCF & Sobowale, 2012 \\
\hline
\end{tabular}

Policy inconsistencies have been a major challenge in the cassava-bread sub-sector. Policy changes followed regime changes. The President Obasanjo regime (1999 2007) mandated $10 \%$ cassava in bread policy (2002) which was reduced to $5 \%$ by the President Yar'Adua's regime (2007 - 2010) and now President Jonathan is implementing $40 \%$. During the period $2000-2008$, wheat importation was controlled (Adebayo et al., 2010) to encourage cassava inclusion in bread. The reasons for the failure of previous cassava in bread policies are listed in Table 3. Unless these challenges are effectively mitigated, the current efforts may also not succeed. For instance, at the peak of implementation of the $10 \%$ cassava inclusion policy in 2006, the price of wheat was $\$ 50,000$ per tonne while cassava flour was $\$ 75,000$ per tonne. Hence, the flour millers did not find any financial incentives to use cassava flour, which they considered to be inferior for bread making. This trend has now reversed. For instance, $50 \mathrm{~kg}$ of wheat flour now sells for $\$ 7,100-8,000$, while HQCF sells for $\$ 4,500$. Adeniyi (2012) reported that cassava bread is now $60 \%$ cheaper than $100 \%$ wheat bread.

Adeloye (2012) reported that earlier policies of cassava inclusion in wheat failed due to poor preparation, deficient logistics, and poor policy implementation strategy. The author wondered what will assure the success of the current effort ( $40 \%$ cassava bread), when previous attempts by different governments have failed including Babaginda (6\%), Obasanjo (10\%), and Yar'Adua (5\%). Sawyerr (2012) reported that implementation of the policy failed due to the reluctance of flour millers to use HQCF, which was 
considered as inferior to and more expensive than wheat as at 2006. The non-purchase of HQCF by the millers caused cassava glut, which discouraged farmers from massive cultivation of the crop in the following year. The rippling effects of this policy failure can have negative impacts on the economy. For instance, there are 164,000 cassava farmers in Nigeria (Olanrewaju, 2012) that could be affected. Alli and Obuh (2012) reported that the HQCF industry alone generates over 3 million jobs from the 75,000 small and medium processing centers. Olanrewaju (2012) reported that many of the 156 small and medium HQCF processing plants shut down when the flour millers stopped buying HQCF. Momoh (2011) reported that each HQCF processing plant has direct employment of 20 workers including peelers, farmers, and transporters. Sawyerr (2012) reported that majority of the HQCF processors are small-scale producing less than 5 tonnes daily. There are few medium scale processors, producing 5 - 30 metric tonnes daily. However, a large scale HQCF processing factory owned by Thai Farmers Ltd. is able to produce 60 metric tonnes HQCF per day and employ about 1000 cassava farmers and spending about $\$ 1$ million daily for the purchase of cassava tubers from farmers. Other large scale $\mathrm{HQCF}$ processor in the country is DADCO producing $60 \mathrm{MT} /$ day HQCF.

There are, however, some positive aspects of previous cassava inclusion in bread policy. For instance, the implementation of the $10 \%$ cassava inclusion in bread policy and the 2002 presidential initiative on cassava has resulted in the increased production of cassava in the country by 10 metric tonnes per year between 2002 and 2008, making Nigeria exceed Brazil and Thailand to become the largest producer of cassava in the world, a position Nigeria has since maintained. Hence, implementation of the current policy of $40 \%$ cassava inclusion could stimulate demand of cassava, encourage utilization, of the product and eradicate glut. The multiplier effects on employment, wealth generation, and rural development cannot be overemphasized. The choice of cassava for bread production is because the crop is versatile, requiring minimal inputs (fertilizer, labour, pesticides). It can grow in poor soil, low water, and still have good yield. In Nigeria, the largest producer of cassava, it is therefore natural to consider the crop suitable for bread production.

Another advantage of cassava inclusion in composite flour is the effects on glycemic index. A recent study indicated that cassava flour had a lower glycemic index of 59.34 compared to wheat flour with a glycemic index of 70.10 among 10 diabetic patients (Fasanmade and Anyakudo, 2007). Ihediohanma (2011)reported that glycemic indices increase with the length of fermentation. The author reported the following glycemic indices of cassava granule (garri) 62 after 24 hours, 67 after 48 hours, and 73 for 72 hours. It is therefore not surprising for unfermented HQCF to have a glycemic index of $<60$. Hence, because of the lower glycemic index of cassava, the composite flour will be healthier for diabetics than $100 \%$ wheat flour.

The production of cassava-wheat composite bread provides opportunities for the fortification of the resultant bread for the purpose of improved nutrition. For instance, it has been recently demonstrated that the blending of cassava with wheat in composite flour can be used as a medium for vitamin A fortification (Aniedu and Omodamiro, 2012; Omodamiro et al., 2012) and fibre enhancement (Jishua and Padmaja, 2008). When composite cassava wheat flour is fortified with legumes, this can further increase the nutritional quality of the bread (Youssef and Bushuk, 1986). Legumes have long been considered a rich source of protein containing three times more protein than cereals (Hefnawy et al., 2012). Furthermore, legumes such as chickpea (Hefnawy et al., 2012), soya bean (Olaoye et al., 2006), and cowpea (Butt et al., 2011) have been reported to contain essential amino acids lacking in wheat bread such as lysine and methionine. Besides, the increase in the protein content of composite flour via legumes fortification has been reported to improve the baking quality of the dough (Butt et al., 2011).

Another reason why previous policy failed is due to the inability of processors to consistently supply HQCFto the mills. The $10 \%$ cassava inclusion policy created a demand of $250-300$ metric tonnes of HQCF per year, which could not be supplied by the processors (UNIDO/FGN, 2006). Sawyerr (2012) reported that most flour mills were only able to achieve $3-5 \%$ cassava flour inclusion at the time the policy collapsed in 2007. Similarly, implementation of $10 \%$ cassava policy in the 1980 s created a demand of 200,000 tonnes of HQCF per year, but only about 10,000 tonnes, i.e. 5\% was supplied (Falade and Akingbala, 2008; Mkpong et al., 1990). Technical challenges experienced during the implementation of the policy will be discussed in the next session of the paper.

\section{Technical Challenges of High Quality Cassava Flour (HQCF) Production in Nigeria}

The processing of fresh cassava roots into HQCF requires peeling, grating, dewatering, sieving and drying (Fig 1). It should be noted that cassava tuber is highly perishable and can go bad within $2-3$ days of harvest. Hence, it must therefore be processed immediately after harvest. The method of flour preparation is important in determining the quality of the cassava flour for bread making. All the processes for the production of flour from cassava used to be done manually. This practice has led to the production of poor quality flours having detects such as yellow coloration, high microbial loads, and odour problems. Manual methods are often slow, producing flour that is fermented or partially fermented, which is unsuitable for bread production. HQCF has to be produced rapidly to prevent fermentation. Nigeria Engineers and Fabricators have made equipment for cassava processing including 
mechanical graters, motorized sieves, and flash dryers (Sanni et al., 2006). Cassava peeling is the most tedious and time consuming operation. Peeling is done manually mostly by women. Manual peeling also increases human contact with the product. Although mechanical peelers have been developed and tested, their use is still not widespread (Ohimain et al., 2013), mostly because of high proportion of wastages. Hence, hand peeling is currently the only feasible option (Kolawole et al., 2012a). Hydraulic jacks are now commonly used for dewatering unlike the traditional method of placing heavy objects, mostly stones, upon sacks containing grated cassava during dewatering. Screw presses have also been developed that are able to reduce the moisture content from $70 \%$ in the grated mash to $47-52 \%$ (Kolawole et al., 2012b).

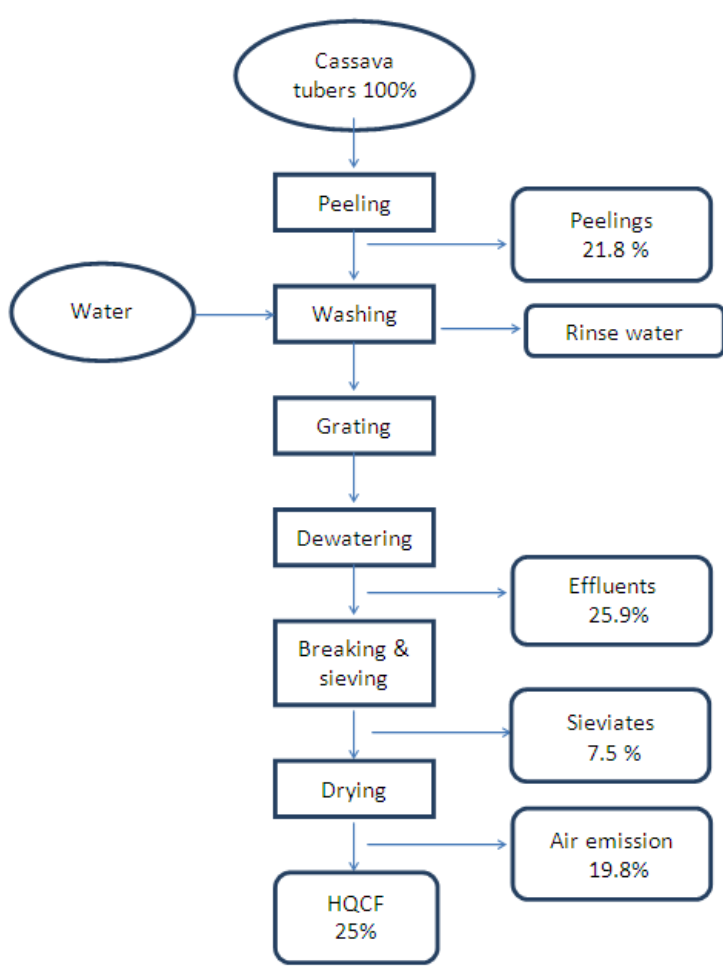

Fig 1. Production of high quality cassava flour (HQCF).

Fermentation takes place if the dewatering process is slow; hence, for the production of unfermented HQCF, the dewatering has to be done rapidly. Kolawole et al.(2012a) reported that improved dewatering system with a mechanical press can successfully dewater grated cassava mash with $2-4$ hours. Cassava flour produced under rapid dewatering systems precluding fermentation mostly produce flour with low $\mathrm{pH}$, which is one of the challenges faced by small processors. The low $\mathrm{pH}$, i.e. acidity, is due to the presence of high level of cyanide that would normally have been removed during fermentation processes. The standard for HQCF is presented in Table 4. The strict requirement of $\mathrm{pH}$ values in the range of $5-8$ is a major challenge for small processors. FAO and IFAD (2004) reported that flour millers fixed the value of HQCF based on $\mathrm{pH}$ value. Onabolu and Bonanga (1998) reported the following prices per $\mathrm{kg}$ of $\mathrm{HQCF}$; 10 at $\mathrm{pH}<4.8$, 12 at $\mathrm{pH} 4.8-5.8$ and $12.00-17.50$ at $\mathrm{pH}>5.8$. Liming is an accepted method for improving the $\mathrm{pH}$ of food substances, but it is a challenge for most small processors.

Table 4. Quality criteria specification of cassava flour set by industrial uses.

\begin{tabular}{llc}
\hline Quality criteria & $\begin{array}{l}\text { Abass et al., 1998; Falade } \\
\text { and Akingbala, 2008 }\end{array}$ & $\begin{array}{c}\text { Sanni et al } \\
\mathbf{2 0 0 5}\end{array}$ \\
\hline pH & $5.0-8.0$ & 1.0 \\
Total acidity, \% & $10-12$ & 10 \\
Moisture content, \% & $<0.9$ & 0.6 \\
Ash, \% & White & \\
Colour & Not detected & \\
Odour & None or sweet & \\
Taste & Absent & \\
Sand or any other & The same as wheat & 10 \\
contaminants & 10 & $65-70$ \\
Cyanticle size & & 2 \\
ppm & & \\
Starch content, \% & & \\
Crude Fibre, \% & & \\
\hline
\end{tabular}

The most energy consuming aspect of HQCF production is the drying stage. Between 2002 and 2006, IITA promoted the use of flash dryers across Nigeria and West Africa for the drying of cassava cake. The flash dryers are able to rapidly dry cassava cake without discoloration and odour problems. But many small processors experienced several problems using locally fabricated flash dryers. Most of the flash dryers produced often breakdown frequently perhaps because the technology has not been well perfected prior to their release into the market. Most of the flash dryers require dual energy sources, diesel or low pour fuel oil (LPFO), to operate the heat exchangers, and electricity to operate the cyclone. In Nigeria, electricity is unstable and of poor quality covering only $40 \%$ of the country and typically not available in most cassava processing sites. Most cyclones require three phase electricity, which cannot be assured in most sites. Hence, many processors rely on diesel generators at very high operational costs. On the other hand, LPFO is scarce and expensive. Nigeria has increased the price of fuel and electricity tariffs several times in the last 10 years. All these have added to the production costs of HQCF. Many processors now use waste engine oil as fuel for the heat exchangers. Two major cost elements have been associated with the high cost of HQCF; the high cost of cassava tuber and cost of drying, which accounted for $50 \%$ and $12.3 \%$ respectively (Oludiran, 2012).

The environmental impact of HQCF processing is quite high, though undocumented. High volumes of waste are typically produced. Ohimain et al. (2013) reported a product conversion of $34 \%$ during the production of garri (a toasted cassava granule) generating 30\% solid, $16.2 \%$ liquid, and $19.8 \%$ gaseous emissions. Peelings alone account for over $20 \%$ of the wastes generated. The conversion ratio for HQCF is 
about 25\% (UNIDO/FGN, 2006), hence, over $75 \%$ of the tuber ends up as wastes. Most cassava processing wastes are not treated, but are freely disposed into the environment causing pollution and odour problems. Household animals such as goats and sheep, and also fish, have been killed by cyanide from cassava effluents (Ohimain et al., 2013). Unfortunately, Owuamanam (2007) reported that the production of unfermented cassava flour for bread making may not address the issue of reduction of cyanide in HQCF. Also the use of fuels like HPFO and waste engine oil to operate flash dryers have led to air quality impacts releasing smokes, particulates, metals, and hydro carbons into the atmosphere. The full environmental impacts of HQCF processing can be overwhelming. Unfortunately, environmental issues pertaining to HQCF have not been addressed by the Federal Ministry of Environment nor the National Environmental Standard and Enforcement Agency (NESREA).

Before the implementation of the $10 \%$ cassava flour inclusion policy in 2002 , there were only two flash dryers in Nigeria (Sanni et al., 2009), but there are now over 160. Oludiran (2012) reported 153 flash dryers in 21 states of Nigeria. The results of a recent survey of 127 dryers showed only 97 were functional (Oludiran, 2012). Another study revealed that of the 156 flash dryers installed in the country, $86 \%$ are classified as poor, having $11 \%$ efficiency, output $103 \mathrm{~kg} /$ hour, and consuming 374 liters of diesel per tonne of HQCF; the remaining $14 \%$ are fair having $32 \%$ efficiency, output of $96 \mathrm{~kg} /$ hour, and consuming 132 liters of diesel per tonne of HQCF as compared to international best practices of $50 \%$ efficiency, $200 \mathrm{~kg}$ /hour, and diesel consumption of $76-80$ litres/tonne (Anonymous, 2012). It appears that the technology and production economics of these locally fabricated flash dryers have not been well tested before being deployed for commercial use. Problems encountered in their operations include frequent breakdown, lack of spare parts, excessive fuel consumption, etc. However, further research $(2006-2008)$ has led to the production of new flash dryers, producing $250 \mathrm{~kg} /$ hour HQCF, which were commissioned in August 2008 (Sanni et al., 2009). Westby et al. (2012) reported a new design in March 2012 having an efficiency of $49 \%$ and output of 202 $\mathrm{kg} /$ hour consuming 86 litres of diesel/tonne of HQCF. Operations of these new flash dryers doubled the output while saving about $\$ 63,000$ /year compared to old model of comparable size. This generation of flash dryers is estimated to cost about $\$ 5,000$ more than the older models, while the cost of upgrading the older models $(\$ 3,000)$ to $41 \%$ efficiency, output of $138 \mathrm{~kg} / \mathrm{hr}$ and diesel consumption of 103 litres/tonnes. Also, locally fabricated mini flash dryers have been developed and tested (Ajao and Adegun, 2009). Electrical/diesel operated rotary dryers (capacity $300 \mathrm{~kg} / 8$ hr) are also used in Nigeria for processing HQCF (Sanni et al., 2009; Oyewole, 2002).

Due to the observed challenges in the operations and maintenance of flash dryers, other innovations have been considered including direct sun drying, solar dryers, and the use of raw cassava tubers instead of cassava flour for bread making. Sun drying of cassava chips has been reported to be effective. When chips are spread at $2.5 \mathrm{~kg} / \mathrm{m}^{2}$ in the rainy season and $3.5 \mathrm{~kg} / \mathrm{m}^{2}$ during the dry season they can produce flour of acceptable bread quality within 8 - 10 hrs (Bokanga, 1995). However, flour mills have raised some quality issues pertaining to flour produced on concrete using sunlight, such as foul odour, sub-optimal colour, high level of sand, or partially fermented flour. Also, sunlight and solar dryers are dependent on diurnal and seasonal influences. In rural areas where cassava tubers are readily available, Falade and Akingbala (2008) advocated the use of minced cassava. This technique has the added advantage of eliminating the need for the energy consuming drying stages.

\section{Challenges of $40 \%$ Cassava Inclusion in Bread Policy}

Wheat flour is ideally suited for bread making. The unique bread making properties of wheat flour are attributed mainly to the ability of its gluten proteins to form a visco-elastic network when mixed with water (Defloor et al. 1993). The dilution of wheat with other flours to form composite flour reduces the bread making potential of the dough (Defloor and Delcour, 1993, Defloor et al. 1993). The detrimental effect of substituted flour on bread making potential increase with increasing levels of substitution. In literature, dough made from composite flour are often better referred to as batters (Houben et al., 2012), perhaps to underscore the difference in their bread making potential. Some of the detrimental effects of wheat substitution on bread making include reduction in loaf volume, crumb structure, product shelf life, and impairment of sensory qualities such as appearance, texture, flavor, and mouth feeling (Shittu et al., 2007; Houben et al., 2012). Osella et al. (2005) reported that gluten-free bread produced with different starches often ages rapidly.

One of the major challenges is the policy itself, which mandated the use of $40 \%$ cassava in bread. Most studies have suggested that $10 \%$ cassava can be used without any effect on bread quality, and $20 \%$, although affecting quality, is acceptable to Nigerians. Table 5 presents the level of cassava inclusion in flour for different products in Nigeria. An increasing level of wheat substitution will require the use of bread making improvers such as hydrocolloids and gums, proteins, enzymes, emulsifying agents, fats and oils (Houben et al., 2012). Of all the options available for improving the quality of cassavawheat bread, the use of emulsifiers appears to be gaining prominence in Nigeria. Falade and Akingbala (2008) reported the use of $10 \%$ emulsion of glyceryl monostearate, while Taiwo (2006) reported the use of calcium stearyl lactylate. Defloor et al. (1991) reported that application of 2 - 3\% of glyceryl monostearate produced cassava-wheat bread of acceptable quality. Though these emulsifiers are 
currently imported, but they could also be produced locally from the by-products of palm oil refining such as palm stearate. Apart from protein sources such as legumes and eggs, which are locally produced in Nigeria, most of the other bread improvers have to be imported at high costs. Although Nigeria has removed the $10 \%$ duty on imported bread improvers, the question remains why would Nigeria reduce wheat importation and start importing bread improvers? Importing bread making improvers will have effects on foreign exchange, which the substitution of wheat is attempting to address in the first instance.

Table 5. Inclusion level of HQCF in different products by different users.

\begin{tabular}{llll}
\hline Users & Product & $\begin{array}{l}\text { Inclusion } \\
\text { HQCF, \% }\end{array}$ & level \\
\hline Bread bakers & Cassava-wheat bread & $5-25$ \\
Biscuit factories & Biscuits & $10-25$ \\
Noodle factory & Noodles & 10 \\
Caterers & Cake & $5-100$ \\
Pasta factory & Pasta & $80-92$ \\
Restaurants & Cassava-maize semo & 18.0 \\
Home caterers & Chin-chin & $25-100$ \\
Home caterers & Fish/meat pie & $10-100$ \\
Home caterers & Buns & $10-12.5$ \\
Home caterers & Fish rolls & $10-12.5$ \\
Home caterers & Puff-puff & $10-25$ \\
\hline
\end{tabular}

Sources: Daramola and Falade (2006); NIFST (2004); Oyewole (2002)

Policy inconsistencies between different governments are another challenge of the current policy. Over the past 20 years, the policy on cassava inclusion in bread has been unstable among successive governments. There was a total ban of wheat importation during the period of 1987 - 1990, whereas from 2002 - 2007, cassava inclusion policy in bread was $10 \%$, which was subsequently reduced to $5 \%$ during 2007 - 2010. In fact beyond 2007, most flour millers reverted to the use of $100 \%$ wheat flour, until the current administration released the $40 \%$ cassava inclusion policy in 2012. If previous policies with lower level of cassava inclusion failed, what would assure the success of the current efforts? Besides, politically, it is doubtful if the current government will have the strong courage to consistently implement the policy. Politically, the current government has exhibited obvious signs of weakness relative to previous administrations. And because of previous cassava policy failures and inconsistencies, the flour millers are skeptical of the current efforts. Besides, nothing has been heard of the 18 large scale HQCF processing plants that were scheduled to be commission in March 2013.

Another major challenge that has emerged early in the implementation of the policy is the inability of HQCF processors to consistently supply cassava of high quality all year round. David (2011) reported that the $10 \%$ cassava bread policy failed in 2005 because of inadequate processing capacity to supply the 350,000 tonnes/year of HQCF demand of the flour mills. Because of the failure of the $10 \%$ cassava bread policy, additional capacity has not been since installed and many flash dryers have closed. Recent surveys show the current capacity of all SMEs producing cassava in Nigeria is 156.61 tonnes/day and two large scale processors with combined capacity of 110 tonnes/day (Oludiran, 2012). Anonymous (2012), in the action plan document for cassava master plan implementation, indicated that there are 103 SME plants (1 - 2 tonnes/day capacity) around Nigeria with a total capacity of 204 tonnes/day, one medium scale processor (Godoligo farm) with an annual capacity of 1,500 tonnes, and two large scale processors (DADCO and Thai farms Ltd) having a combined capacity of 10,000 tonnes/year. It was also reported that as of 9 September 2011, only 14 of the SMEs are operational due to lack of purchase of flour by the flour millers. If all the SMEs and large scale HQCF plants are working all year round at full capacity (100\%), the country is only able to produce $204 \times 365+10,000+$ $1,500=85,960$ tonnes/year, which can only meet about $7.16 \%$ of the 1.2 million tonnes of HQCF required by the $40 \%$ cassava inclusion policy. It is therefore very clear that the local processors (small, medium and large scale) would be unable to supply the HQCF demand of the policy, at least in the short term, until the Federal Government completely install the planned 18 large scale HQCF processing plants.

The large quantity of flour required to fully implement the policy translates to a huge cassava tuber demand of 4.8 million tonnes per year. It is doubtful if Nigeria is able to supply this additional demand of cassava in the short term. About $90 \%$ of the cassava produced in many West Africa countries including Nigeria is used for the production of fermented traditional foods such as garri, fufu, loi-loi, amala, akpu, lafun, etc., (Oyewole, 2002), hence only 10\% is left for other purposes. Therefore, of the 36.8 million tonnes of cassava produced in Nigeria in 2009, only less than 4 million tonnes is available for other purposes. Whereas since the implementation of the presidential initiative on cassava in 2002, other competing uses have emerged for cassava in other sectors including beverages, pharmaceutical, textile, feed industry, starch industry, etc. (Philips et al., 2004). Cassava is also actively promoted for the production of biofuel (bioethanol in Nigeria and several cassava ethanol projects are under construction in Nigeria (Ohimain 2010, 2013a). In addition, the government has received orders from China requesting for cassava chips. With these conflicting uses of cassava, it is therefore uncertain if the demand for HQCF can be met in the short term. Besides, the cassava flour value chain in Nigeria is weak, unstable and un-reliable with the resultant effects of cassava scarcities occurring in certain areas, while glut is being experienced in other areas.

Increase in cassava demand would necessitate increase in production. Nigeria needs to increase both the yield and area of cassava farms. It has been reported that about $99 \%$ of Nigerian cassava farmers are small holders with farm sizes in the range of $1-5$ ha, which is often inter-cropped with yam, maize, or legumes (Anonymous, 2012). Most of these farms 
are cultivated manually using rudimentary equipment and without the application of agrochemicals. Most of the farms are not serviced by irrigation; hence they are dependent on rainfall. Rain fed agriculture is often affected by climatic variability, which is becoming more relevant owing to the observed climate change. Many farmers still plant poor yielding cassava varieties, despite the fact that high yielding and disease resistant varieties have been released to farmers. Because of these and other factors, the yield of cassava planted in Nigeria is relatively poor being 11 tonnes/ha, which is several orders lower than $20-45$ tonnes/ha recorded in Brazil and Thailand (UNIDO/FGN, 2006). Nigeria therefore needs to urgently increase yield, the area cultivated, and adopt modern farm practices such as mechanization, use of fertilizers and agrochemicals, irrigation, and large scale farming techniques.

The incentives under this policy may be insufficient to establish a stable cassava-bread industry. Experience from the implementation of similar policy on biofuel (Ohimain, $2010,2013 a, 2013 b)$ suggest that additional policy incentives may be required such as grants, loans, and subsidies. It should be noted that wheat is highly subsidized in most producing countries, thus the price of wheat is low in these countries. Nigeria institutions are quite weak, especially customs and border controls. Hence, there are fears that the increase in the tariff and duty of imported wheat flour and wheat grain to $100 \%$ and $20 \%$ respectively could encourage smuggling (David, 2011) as currently witnessed in the poultry sector. For instance, Nigeria lost 32 Billion to rice smuggling in 2012 alone (RIMDAN, 2012). Smuggling could jeopardize the success of the cassava bread policy.

\section{Conclusion and Recommendations}

The idea of partially substituting wheat with cassava is a welcome development for many wheat importing nations like Nigeria. Since 1987, the country has inconsistently released several policies in an attempt to substitute cassava flour for wheat. The paper assessed previous policy failures in an attempt to avoid the pitfalls of previous attempts. Several challenges that made previous policies fail can threaten the current attempt including;

Poor HQCF supply chains.

Weak policy implementation.

Reluctance of millers to use cassava flour.

Technological challenges.

Insufficient capacity of HQCF processors to meet the policy demand.

Insufficient policy incentives.

Processing challenges.

Quality challenges especially concerning flour fermentation, $\mathrm{pH}$ and cyanide levels.

Cassava bread policy instability.

Notwithstanding, there are issues that have emerged, which could favour the actualization of the policy relative to previous attempts;
Unlike during previous attempts, cassava flour is now cheaper than imported wheat.

Increase in the tariff/duty of wheat flour to $100 \%$ and wheat grain to $20 \%$.

Complete removal of duty from bread improvers.

Establishment of cassava bread development fund for training and enforcement of HQCF value chain.

Multiplier effects on employment, wealth creation and rural development is expected to increase.

Electricity supply and coverage have improved slightly.

However, certain issues could be worsening relative to precious attempts, such as;

Larger quantity of HQCF is required by the policy, which local processors may not be able to supply.

If cassava inclusion policies of $5 \%$ and $10 \%$ failed or could not be sustained what would assure the success or sustainability of $40 \%$ cassava inclusion.

High level of wheat substitution negatively impacts bread making potential, thus necessitating the use of imported enzymes and improvers, which are costly in addition to depleting the country's foreign exchange.

Increased tariff/duty on wheat flour and grain could encourage smuggling, which could threaten the nascent cassava bread sub-sector.

Price of bread production has increased caused by several confounding factors including wheat import restrictions, and increased cost of bread additives such as sugar and margarine.

Increased wheat substitution translate to increase flour and tuber demand, which could increase environmental impacts such as solid wastes, air emissions and effluent generation and discharge, expansion of farms into virgin lands, intensification of cassava farm involving farm mechanization, irrigation and the use of agrochemicals (fertilizer and herbicides).

The cost of milling flour has increased in Nigeria due to the combined effect of increased wheat importation tariff and duty as a result of the policy and price hikes of fuel and electricity.

Many HQCF processing plants have shut down.

Cost of HQCF processing has increased due to increase in fuel and electricity tariffs.

In view of the challenges and threat to the implementation of the policy, the following issues are recommended;

The previous $10 \%$ cassava policy should be sustained for a long time before ever considering $40 \%$.

The government should continue the training of millers and bakers on the use and importance of cassava bread.

$40 \%$ cassava flour inclusion should be implemented gradually.

There is the need to completely overhaul and modernize the entire sector with the use of farm mechanization, irrigation, application of fertilizer and herbicides.

Large scale farming should be encouraged.

Nigeria needs to increase yield and the area of cassava farm cultivated. 
Sensitization of the public towards the acceptability of cassava bread.

Encourage the domestic production of bread improvers.

Continue research and development especially on other less utilized crops such as coco yam, sweet potatoes for bread production.

\section{Acknowledgement}

The author wishes to thank Sylvester C. Izah for the editorial work and Dr. Donna Jacob of North Dakota State University for proofreading the manuscript.

\section{References}

[1] Abass, A.B., Onabolu, A.O., Bokanga, M., 1998. Impact of the high quality cassava flour technology in Nigeria. In: Akoroda, M.O. and Ngeve, J.M. (compilers).In root crops in the $21^{\text {st }}$ century. Proceedings of the $7^{\text {th }}$ Triennial symposium of the international society for tropical root Crops-Africa Branch (ISTRC-AB). Centre international des Conferences, Cotonou, Benin. 11 - 17 October, 1998.

[2] Abdelghafor, R.F., Mustafa, A.I., Ibrahim, A.M.H., Krishnan, P.G., 2011. Quality of bread from composite flour of sorghum and hard white winter wheat. Adv. J. Food Sci. Technol. 3, $9-15$.

[3] Aboaba, O.O., Obakpolor, E.A., 2010. The leavening ability of baker's yeast on dough prepared with composite flour (wheat/cassava). Afr. J.Food Sci. 4, 325 - 329 .

[4] Adebayo, K., Abyomi, L., Abass, A., Dziedzoave, N.T., Forsythe, L., Hillocks, R.J., Gensi, R., Gibson, R.W., Graffham, A.J., Ilona, P., Kleih, U., Lamboll, R.I., Mahende, G., Martin, A.M., Onumah, G.E., Orr, A.W., Posthumus, H., Sanni, L.O., Sandifolo, V., Westby, A.,2010. Sustainable inclusion of smallholders in the emerging high quality cassava flour value chain in Africa: challenges for agricultural extension services. J. Agric. Extens. 14, 1 - 10.

[5] Adebile, O.A.,2012. Employment Generation through Agriculture, a case study of cassava production in Nigeria. Inter. Rev. Bus. Soc. Sci. 1, $70-84$.

[6] Adebowale, A.A., Adegoke, M.T., Sanni, S.A., Adegunwa, M.O., Fetuga, G.O., 2012. Amer. J. Food Technol. 7, $372-$ 379.

[7] Adeloye, L., 2012. FIIRO seeks stakeholders' support on cassava policy. Punch, July 20, 2012.

[8] Adeniji, T.A., Hart, A.D., Tenkouano, A., Barimalaa, I.S., Sanni, L.O., 2010. Comparative study of pasting properties of improved plantain, banana and cassava varieties with emphasis on industrial application. Afr.J.Food, Agric.Nutr. Dev. 10, $2601-2614$.

[9] Adeniyi, S., 2012. Cassava bread is good for diabetics-NSN President. Nigeria Tribune, Tuesday June 19, 2012.

[10] Ajao, K.R., Adegun, I.K., 2009. Performance evaluation of a locally fabricated mini cassava flash dryer. J. Agric. Technol. $5,281-289$.

[11] Alli, F., Obuh, P., 2012. 15\% duty on wheat escalates prices of flour-based products. Vanguard September 24, 2012

[12] Alvarenga, N.B., Lidon, F.C., Belga, E., Motrena, P., Guerreiro, S., Carvalho, M.J., Canada, J., 2011. Characterization of gluten-free bread prepared from maize, rice and tapioca flours using the hydrocolloid seaweed agaragar. Recent Res. Sci. Technol. 6, 64-68.

[13] Aniedu, C., Omodamiro, R.M., 2012. Use of newly bred $\beta$ carotene cassava in production of value-added products. Implication for food security in Nigeria. Glo. J. Sci. Fron. Res. $12,11-16$.

[14] Anonymous., 2012. Action plan for a cassava transformation in Nigeria. Draft Report. http://www.unaab.edu.ng/attachments/Cassava\%20Report\% 20Final.pdf accessed 8 June 2013

[15] Babatunde, J.,2012. 40\% cassava inclusion in flour: are the millers fighting back? Vanguard, June 08, 2012.

[16] Bokanga, M.,1995. Cassava opportunities for the food, feed, and other industries in Africa. In: Egbe, T.A., Griffon, D. and Treche, S. (eds.). Transformation Alimentaire du Manioc, OSTRO Editions, Paris.pp 557 - 569

[17] Butt, M.S., Iqbal, J., Naz, A., Sulerial, H.A.R., Qayyum, M.M.N., Saleem, F., Jahangir, M.A.,2011. Effect of flour blending on bread characteristics. Internet J. Food Saf. 13, $142-149$.

[18] Daramola, B., Falade, K.O., 2006. Enhancement of agronomical values: upstream and downstream opportunities for starch and starch adjuncts. Afr. J. Biotechnol. 5, 2488 - 2494.

[19] Das, L., Raychaudhri, U., Chakraborty, R., 2012. Effects of baking conditions on the physical properties of herb bread using RSM. Inter. J. Food Agric. Veter. Sci. 2, 106 - 114.

[20] David, M., 2011. GON plans to introduce import restrictions. Global Agriculture Information Network. USDA Foreign Agriculture Service.

[21] Defloor, I., Delcour, J.A., 1993. Impact of milling procedure on bread-making potential of cassava flour in wheatless breads. Cereal Chem. 70, 616-617.

[22] Defloor, I., De Geest, C., Schellekens, M., Martens, A., Delcour, J.A.,1991. Emulsifiers and/or extruded starch in the production of breads from cassava. Cereal Chem. 68, $323-327$.

[23] Defloor, I., Nys, M., Delcour, J.A., 1993. Wheat starch, cassava starch, and cassava flour impairment of the breadmaking potential of wheat flour. Cereal Chem. 70, 526 -530 .

[24] Dendy, D.A.V., 1993. Review of composite flour technology in the context of Tanzania. A paper presented at the workshop. Sorghum and millets marketing and utilization, Arusha Tazania, 3 - 5 May 1993.

[25] Dendy, D.A.V.,1992. Composite flour-past, present, and future: A review with special emphasis on the place of composite flour in the semi-arid zones. In: Gomez, M.I., House, L.R., Rooney, L.W., Dendy, D.A.V., (eds.). Utilization of sorghum and millets. International crops institute for the Semi-Arid Tropics, Patancheru, Andhra Pradesh 502324 India. pp. 67-73 
[26] Echebiri, R.N., Edaba, M.E.I., 2008. Production and utilization of cassava in Nigeria: Prospects for Food Security and infant nutrition. PAT 4, 38-52.

[27] Falade, K.O., Akingbala, J.O., 2008. Improved nutrition and national development through the utilization of cassava in baked foods. In: Robertson, G.L., Lupien, J.R. (eds.). Using food science and technology to improve nutrition and promote national development. International Union of Food Science and Technology.http://www.iufost.org/publications/books/docum ents/Chapter10FaladeAkingbala.pdfaccessed 8 June 2013

[28] FAO., IFAD., 2004. Global cassava market study. Business opportunities for the use of cassava. Proceedings of the validation forum on the global cassava development strategy. International fund for agricultural development food and agriculture organization of the united nations, Rome, 2004.

[29] Fasanmade, A.A., Anyakudo, M.M.C., 2007. Glycemic indices of selected Nigerian flour meal products in male type 2 diabetic subjects. Diabet. Croat. 36, $33-38$.

[30] Gray, J.A., BeMiller, J.N., 2003. Bread staling: molecular basis and control. Compreh. Rev. Food Sci. Food Saf. 2, 1 - 6 .

[31] Hefnawy, T.M.H., El-Sourbagy, G.A., Ramadan, M.F.,2012. Impact of adding chickpea (Cicer arietinum L.) flour to wheat flour on the rheological properties of toast bread. Inter. Food Res. J. 19, $521-525$.

[32] Houben, A., Hochstotter, A., Becker, T., 2012. Possibilities to increase the quality in gluten-free bread production: an overview. Eur. Food Res. Technol. 235, 195 - 208.

[33] Ihediohanma, N.C., 2011. Determination of the glycemic indices of three different cassava granules (Garri) and the effect of fermentation period on their glycemic responses. Pak. J. Nutr. 10, 6 -9.

[34] Ikuomola, V.,2012. Jonathan to Nigerians: eat cassava bread, confectionaries. The Nation April 30, 2012.

[35] Ituen, E.U.U., Ituen, I.S., 2011. Selecting cassava varieties for composite bread. World J.Appl.Sci. Technol. 3, 61 - 71.

[36] Jishua, S., Padmaja, G.,2008. Dietary fiber enhancement in cassava based composite flours through fortification. J. Root Cro. 34, $26-33$.

[37] Kolawole, O.P., Agbetoye, L.M., Ogunlowo, A.S., Sanni, L., Adebayo, A., 2012a. Innovative development of cassava processing machine as solution to crises against agricultural systems. Conference on International Research on Food Security, Natural Resource Management and Rural Development organized by: Georg-August Universitat and University of Kassel-Witzenhausen. Held $19-21$ September, 2012. Tropentag, Gottingen, Germany.

[38] Kolawole, O.P., Agbetoye, L.A S. Ogunlowo, A.S., Samuel, T.M., 2012b. Effect of speed and back pressure on the performance of screw press in dewatering of cassava mash. Green. J. Sci. Eng. Technolo. Res. 2, $017-023$.

[39] Komlaga, G.A., Glover-Amengor, M., Dziedzoave, N.T. and Hagan, L.L., 2012. Consumer acceptability of wheat cassava composite bread. World Rur. Observ. 4, $78-81$.

[40] Maziya-Dixon, B., Dixon, A.G.O., Adebowale, A-R.A., 2007. Targeting different end uses of cassava: genotype variations for cyanogenic potentials and pasting properties.
Inter. J. Food Sci. Technol. 42, 969 - 976.

[41] Mkpong, O.E., Yan, H., Chism., G., Sayre, R.T.,1990. Purification, characterization and localization of linamarase in cassava. Plant Physiol. 93, $176-181$.

[42] Momoh, S.,2011. Bakeries to enjoy smooth transition to $40 \%$ cassava bread. Business day, Friday December 16, 2011.

[43] NIFST.,2004. Food Forum. A publication of Nigerian Institute of Food Science and Technology (NIFST). 3(1): 20.

[44] Nigerian Tide., 2012. Institute tasks bakers on cassava flour. Nigeria Tide, November 14, 2012.

[45] Nuwamanya, E., Baguma, Y., Emmambux, N.,Rubaihayo, P., 2010. Crystalline and pasting properties of cassava starch are influenced by its molecular properties. Afr. J. Food Sci. $4,008-015$.

[46] Ogunbawo, S.T., Adebayo, A.A., Okanlawon, B.M., Edema, M.O., 2008. Effects of lactic acid bacteria and Saccharomyces cerevisiae co-cultures used as starters on the nutritional contents and shelf life of cassava-wheat bread. J. Appl. Biosci. 12, 612 - 622.

[47] Ogunjobi, M.A.K., Ogunwole, S.O., 2010. Physicochemical and sensory properties of cassava flour biscuits supplemented with cashew apple powder. J. Food Technol. 8, $24-29$.

[48] Ohimain, E.I., 2010. Emerging bio-ethanol projects in Nigeria:Their opportunities and challenges. Energ. Policy. $38,7161-7168$

[49] Ohimain, E.I., 2013a. Can the Nigerian biofuel policy and incentives (2007) transform Nigeria into a biofuel economy? Energ. Policy. 54,352-359.

[50] Ohimain, E.I., 2013b.A review of the Nigerian biofuel policy and incentives (2007). Renew. Sustain. Energ. Rev. $22,246-256$

[51] Ohimain, E.I.,Silas-Olu, D.I., Zipamoh, J.T., 2013. Biowastes Generation by Small Scale Cassava Processing Centres in Wilberforce Island, Bayelsa State, Nigeria. Green. J. Environ. Manage. Publ. Saf.2, 51 - 59

[52] Olanrewaju, S., 2012. We are triggering cassava-based industrial revolution - Adesina. Nigerian Tribune, August 14, 2012

[53] Olaoye, O.A., Onilude, A.A., Idowu, O.A., 2006. Quality characteristics of bread produced from composite flour of wheat, plantain and soybeans. Afr. J. Biotechnol. 5: $1102-$ 1106.

[54] Oludiran, A.,2012. Prospects for cassava flour incorporation in bread making in Nigeria. FHI 360, Abuja, Nigeria

[55] Omodamiro, R.M., Oti, E., Etudaiye, H.A., Egesi, C., Olasanmi, B., Ukpabi, U.J. 2012. Production of fufu from cassava roots using the ordourless four technique and the traditional method: Evaluation of carotenoids retention in the fufu. Adv. Appl. Sci. Res. 3, 2566-2572.

[56] Onabolu, A.,Bonanga, M.,1998. The promotion of cassava as a commodity for the food industry: a case study in Nigeria. Presented at the CFC workshop on local processing and vertical diversification of cassava in southern and eastern Africa, 15 - 19 June 1998. Mukono, Uganda. 
[57] Osella, C.A., Sanchez, H.D., Carrara, C.R., de la Torre, M.A., Buera, M.P., 2005. Water redistribution and structural changes of starch during storage of a gluten-free bread. Starch 57: $208-216$.

[58] Owuamanam, C.I., 2007. Quality of bread from wheat/cassava flour composite as affected by strength and steeping duration of cassava in citric acid. Nat. Sci. 5, $24-$ 28.

[59] Oyebode, W., Akinola, T., 2012. UTC'S bread components now 22 per cent cassava flour. Guardian Monday April 23, 2012 .

[60] Oyewole, O.B., 2002. The powers at the roots: food and its microbial allies. An inaugural lecture delivered at the University of Agriculture, Abeokuta, Nigeria. October 9, 2002.

[61] Oyewole, O.B., Sanni, L.O. and Ogunjobi, M.A., 1996. Production of biscuits using cassava flour. Nig. Food J. 14: $24-29$.

[62] Phillips, T.P., Taylor, D.S., Sanni, L., Akoroda, M.O., 2004. A cassava industrial revolution in Nigeria; the potential for a new industrial crop. The Global Cassava Development Strategy. IFAD/ FAO, Rome.

[63] Pite, M., 2008. Gluten naIndustia Alimentar - comogarantir a seguranca a consume doresceliacos. Seguranca e Qualidade Alimentar. Pp. 34 - 36.

[64] RIMDAN., 2012. N 32 billion lost to rice smugglers. Rice Importers and Distributors Association of Nigeria. The Nation Newspaper 8 March 2012.

[65] Sanni, L.O., Christiana, A.B.,Silifat, A.S.,2004. Production of instant cassava noodles. J. Food Technol. 2, $83-89$

[66] Sanni, L.O., Maziya-Dixon, B., Akanya, J.N., Okoro, C.I., Alaya, Y., Egwuonwu, C.V., Okechukwu, R.U., Ezedinma, C., Akoroda, M., Lemchi, J., Ogbe, F., Okoro, E., Tarawali, G., Mkumbira, M., Patino, M., Ssemakunla, G., Dixon, A., 2005. Standard for cassava products and guidelines for export. International Institute of Tropical Agriculture (IITA). Standard Organization of Nigeria.

[67] Sanni, L., Maziya-Dixon, B., Onabolu, A.O., Arowosafe, B.E., Okoruwa, A.E., Okechukwu, R.U., Dixon, A.G.O., Waziri, A.D.I., Ilona, P., Ezedinma, C., Ssemakunla, G., Lemchi, J., Akoroda, M., Ogbe, F., Tarawali, G., Okoro, E., Geteloma, C., 2006. Cassava recipes for household food security. International Institute of Tropical Agriculture (IITA) Integrated Cassava Project, Ibadan, Nigeria.
[68] Sanni, L.O., Onadipe, O.O., Ilona, P., Mussagy, M.D., Abass, A., Dixon, A.G.O., 2009. Successes and challenges of cassava enterprises in West Africa: a case study of Nigeria, Benin, and Sierra Leone. International Institute of Tropical Agriculture (IITA)

[69] Sawyerr, S., 2012. Cassava bread: the bittersweet taste. Tell Magazine 2012

[70] Shittu, T.A., Raji, A.O., Sanni, L.O., 2007. Bread from composite cassava-wheat flour: I. Effect of baking time and temperature on some physical properties of bread loaf. Food Res. Inter. 40, $280-290$.

[71] Sobowale, D., 2012. Mistaken notions about food policy-1 (cassava bread as case study). Vanguard July 9, 2012.

[72] Taiwo, K.A.,2006. Utilization potentials of cassava in Nigeria: the domestic and industrial products. Food Rev. Inter. $22,29-42$.

[73] Tarawali, G., Iyangbe, C., Udensi, U.E., Ilona, P., Osun, T., Okater, C., Asumugha, N., 2012. Commercial-scale adoption of improved cassava varieties: A baseline study to highlight constraints of large-scale cassava based agroprocessing industries in southern Nigeria. J. Food, Agric. Environ. 10, 689-694.

[74] UNIDO/FGN., 2006. Nigeria Cassava Master Plan (NCMP) United Nations Industrial Development Organization and Federal Government of Nigeria.

[75] Vanguard.,2012. With cassava, wheat in our flour we can tackle diabetes. Vanguard June 11, 2012.

[76] Westby, A., Dziedzoave, N.T., Sandiolo, V., Sanni, L.O., Adebayo, K., Alacho, F.O., Makinde, G., 2011. Cassava adding value in Africa. Natural resources Institute. http://cava.nri.org.

[77] Westby, A., Adebayo, K., Sanni, L., Dziedzoave, N., Sanifolo, V., Mahende, G., Alacho, F., Graffham, A., Adeyomi, L., Posthumus, H., Martin, A., Hillocks, R., Forsythe, L., Lamboll, R., Ilona, P., Abass, A., 2012 Cassava: Adding Value for Africa (C:AVA) Project Update. Presentation in Kampala, Uganda. cava.nri.org/.../pps/2_Adebayo_et_al_GCP_21_Kampala_S HOW.pps accessed 8 June 2013

[78] Youssef, M.M., Bushuk, W., 1986. Bread making properties of composite flours of wheat and faba bean protein preparations. Cereal Chem. 63, 357-361. 